\title{
DISEASE - A WELFARE COMPROMISE
}

\author{
J. S. J. ODENDAAL \\ Life Sciences Research Institute, Technikon Pretoria, Private Bag X680, Pretoria, 0001, South Africa. \\ Received June 2, 2000 \\ Accepted February 7, 2001 \\ Abstract \\ Odendaal J. S. J. : Disease - a Welfare Compromise. Acta Vet. Brno 2001, 70: 97-104. \\ Veterinarians usually attempt to find the direct cause of diseases, trauma or behavioural \\ problems, in order to decide on an appropriate therapeutic regimen. They rarely ask what causes \\ the causes. As in the popular media, one should inquire about the story behind the story. Such an \\ approach will inevitably have an influence on the veterinarian's therapeutic decisions. Owing to \\ the veterinarian's technical skills and all the wonder drugs readily available on the shelves, it has \\ become much easier to impress clients with surgery and medicine. However, if veterinarians \\ thought that their involvement in animal welfare should be merely that of a biological mechanic, \\ they are missing the point. \\ Veterinary Science, animal welfare, paradigm shift
}

Veterinarians often believe that their contribution to animal welfare is contained in their clinical work. What then is animal welfare and well-being if it is not healing? Is the emotional and sentimental feeling for neglected and homeless animals the real thing? If we as humans want to take charge of animals through responsible ownership and guardianship, our mission should not in the first place be to save already diseased, traumatised or neglected animals, but to focus primarily on preventing such conditions. The question is thus, when are animals "faring well", and when are they "being well"? Certainly not when they are ill, injured or maladapted. Neither a biological-mechanical approach nor the emotional saving of animals intrinsically has anything to do with the animal's experience of being well, because those approaches come too late, i.e. at a time when the animal's well-being has already been lost. Furthermore, these efforts to restore lost well-being could be of a temporary nature. They offer immediate relief from suffering and misery - often only until the next time. Animal welfare and well-being should be more than relieving immediate suffering, and it should involve more than an emotional feeling.

\section{Human Medicine}

Even in human health, it is realised by some scientists that clinical work, although it has its place, is but a part of the disease story. Lew ontin (1993), a leading geneticist from Harvard University, reviewed the history of diseases in modern Europe. He claimed that death rates from fatal diseases such as respiratory conditions and tuberculosis declined in the nineteenth century. Robert Koch's germ theory of 1876 had no effect on the morbidity of diseases and by the time drug therapy was introduced to combat tuberculosis early this century, more than $90 \%$ of the decrease in mortalities from this disease had already occurred. Lewontin's story behind the story goes as follows:

"Although one may say that the tubercle bacillus causes tuberculosis, we are much closer to the truth when we say that it was the conditions of unregulated nineteenthcentury competitive capitalism, unmodulated by the demands of labour unions and

Address for correspondence:

Prof. Dr. Johannes Odendaal

P.O.Box 17855

0116 South Africa 
the state, that was the cause of tuberculosis. But social causes are not in the ambit of biological sciences, so medical students continue to be taught that the cause of tuberculosis is a bacillus" (Lew ontin 1993, p. 45).

On asbestos causing cancer, he continues:

"The transfer of causal power from social relations into inanimate agents that then seem to have a power and life of their own is one of the major mystifications of science and its ideologies" (Lew ontin 1992, p. 46).

What happens here is that the clinical diagnosis tells us to look for causes of causes, otherwise only a small part of the facts becomes accepted as medical science. If science has to reflect the truth as well as reality, it seems that if scientists only consider direct causes they have chosen their "own truth and reality". From a positivistic point of view, such loss of objectivity is one of the deadly sins of science.

Mind and Body

Sternberg (I 995) stated that health psychology in humans is a relatively new branch of psychology, despite the fact that the mind-body debate is not a new one. Health psychologists study the psychological antecedents and consequences of how people remain healthy, how they become ill or prevent illness and how they respond or adapt to illness in order to cope with and overcome it. Matters such as diet programmes (nutrition), recreation or play and sleep (i.e. active and passive relaxation behaviour), healthy sexual behaviour (including reproductive planning), prevention of illness and injury (hygiene), the taking of drugs in order to cope with the environment (instead of safe, environmental enrichment and exercise), healthy development and functioning of the nervous system (training, stimulation and fulfilling attention-seeking behaviour), social needs (interaction and group affiliations), family problems (care and housing facilities) and the effect thereof an health and well-being, are considered. (The words in brackets were added by the author.)

The interaction between psychological and physiological processes works both ways. Although it is arguable whether psychological factors actually cause psychosomatic diseases, they will at least exuberate such diseases. On the other hand, the effect of disease on the mind can be studied in the response of the body to acute and chronic illness and injury. There are, in human medicine today, two models in illness. One is the biomedical where disease is caused by pathogens that have invaded the body. This model has successfully served the medical profession for almost 2000 years, providing a basis for treating and even curing diseases. Some medical scientists consider this model, as alluded to above, too mechanistic and too narrow in scope, because it gives little consideration to how to promote wellness (Sternberg 1995).

An alternative model is the biopsychological model according to which psychological and social factors, as well as biological factors, can influence health (Engel 1977; Schwartz 1982). This model adds to Lew ontin's (1993) arguments and it underscores the importance of context in understanding health and illness. For example, most people believe that factors such as changes in weather, poor diet, lack of sleep and stress can contribute to catching a cold (Lau and Hartman 1983). The primary goal of health psychology is thus to promote health and health-enhancing behaviour and people can, inter alia, significantly reduce their risk of dying, almost linearly at any given age by following seven health-related practices, viz:

- sleeping 7-8 hours a day (relaxation)

- eating breakfast almost every day (nutrition, routine)

- rarely eating between meals (nutrition, routine)

- being at a roughly appropriate weight in relation to height (nutrition and exercise) 
- not smoking (safe, enriched environment and facilities which can decrease stress)

- drinking alcohol in moderation or not at all (as previous one)

- regular physical activity (exercise).

Apart from things not to do, positive steps can also be taken to enhance health through nutrition and exercise (Belloc and Breslow 1972; Bre slow 1983). The words in brackets behind the seven practices were added by the author and it is suggested that two more healthrelated practices be added to this list, viz hygiene and positive social interaction.

Sternberg (1995) compared the 10 leading causes of death in humans in 1900 and in 1992 by using death rates caused by the condition per 100000 people. The diseases were:

1900

$\begin{array}{lr}\text { Influenza } & 202 \\ \text { Tuberculosis } & 194 \\ \text { Gastro-enteritis } & 143 \\ \text { Heart disease } & 137 \\ \text { Stroke } & 107 \\ \text { Kidney disease } & 81 \\ \text { Accidents } & 72 \\ \text { Cancer } & 64 \\ \text { Infancy diseases } & 63 \\ \text { Diphtheria } & 40\end{array}$

1992

$\begin{array}{lr}\text { Heart disease } & 283 \\ \text { Cancer } & 204 \\ \text { Stroke } & 56 \\ \text { Chronic lung disease } & 36 \\ \text { Accidents } & 34 \\ \text { Influenza } & 30 \\ \text { Diabetes } & 20 \\ \text { HIV } & 13 \\ \text { Suicide } & 12 \\ \text { Homicide } & 10\end{array}$

During this century, the trend has been away from acute infectious diseases and towards chronic stress-related diseases.

\section{Simplicity and Complexity}

According to Lew ontin (1993), the decline of infectious diseases is not always directly linked to a medical solution, but also to changes in the environment. This theory seems to be borne out when one considers the early prediction of AIDS deaths about 15 years ago and what is actually happening now, before any medical cure has been found. The complex interplay between macro-factors in the environment and large populations is difficult to predict when linear thinking about cause and effect, that is so popular in medical sciences, is applied. Mathematical formulae and figures are often proven wrong by biological reality (Lindley 1993).

Mathematics - measuring and working with numbers - has also been the driving force behind reductionism. If one could find the smallest particle in the micro-world and measure it, one could add them up in numbers, which would then help to understand the macro-world. Mathematics is that particular language of natural scientists in which they express their messages and this language is highly applicable in the so-called hard sciences. However, relativity and especially quantum physics, the modern physics of this century, have placed a new meaning on measurement and the definition of the smallest particle. These concepts emphasize ambiguity and ambivalence, rather than presenting simple formulae which explain the fundamental basis of the entire macro-world. Measuring space-time depends on "where", because there is no absolute universal time. Measuring particles depends on "who", because it cannot be done without the involvement of the researcher, the factor which should have been the objective outsider. In quantum physics man, apparatus and method all play a role in the outcome of the results and the smallest particle disappears in a process based on the principle of uncertainty and probability. In the classical world, our observations do not create reality, but uncover it. In the quantum world, however, observations alone create reality (Davies 1990). 
From this revelation in the micro-world, the pursuit of a Theory of Everything or the socalled TOE (Weinberg 1991) seems futile. The focus has shifted from the search for one simple equation to an attempt to explain complexity, searching for a Theory of Organization or the so-called TOO (Prigogine and Sten gers 1985; B arrow 1991). It was realised that the smallest particles added up will not explain the macro-structures and the interaction thereof, and this is particularly true in biology. Theories of organization should thus explore approaches other than the simplicity of measurable atoms and linear formulae, when complex systems are studied. There is as yet, according to Davies (1995), no clear-cut explanation for such systems. He said that because of the evident problems in understanding complexity and self-organisation, there is no agreement on the source of nature's organising potency. Cohen and Stew art (1994), believe that our current prized laws of nature are not ultimate truths, rather mere well-constructed Sherlock Holmes stories:

"But those stories have been scrubbed and polished, over the centuries, until they capture very significant features of the way the universe works. That's what laws of nature are" (Cohen and Stewart 1994, p. 435).

These authors stated that reductionism is useful but does not give the whole truth - it tells us how but not why, it looks at insides but not at outsides, content but not context.

Organism and environment

It is clear that organisms in themselves are complex systems, but they do not operate and survive without an environment. The interaction between organism and environment contributes to further complexity:

"Modern biology has become completely committed to the view that organisms are nothing but the battle grounds between the outside forces and the inside forces", however, "just as there is no organism without an environment, there is no environment without an organism. Organisms do not experience environments. They create them.

They construct their own environments out of the bits and pieces of the physical and biological world and they do so by their activities" (Lew ontin 1993, p. 109).

With regard to genetics (inside forces), Lew ontin (1993) argued that it takes more than DNA to make a living organism, because environmental and genetic variations are not independent pathways. Genes affect how sensitive an organism is to the environment and environment affects how relevant the organism's genetic differences may be. The interplay between organism and environment is thus indissoluble. Genetic and environmental effects can be separated statistically only in a particular population of organisms at a particular time with a particular set of specif ied environments. Changes can occur in environments as well as in genes, which can be switched on or off.

Modern Science and Veterinary Science

Justifiably, one may ask what the relation is between all this and animal welfare and wellbeing? Is it another attempt at a mystic holism, which forms part of a New Age philosophy? No, this background represents the latest insight in mainstream science. These are the facts we also have to deal with in veterinary science. The very practical and usable linear and reductionist approach is simply not the ultimate knowledge any more, and veterinarians are to be cleverer than biological mechanics.

To bring the background knowledge into an animal welfare perspective, the following summary can be useful:

1. A simplistic cause-and-effect approach to medicine can be regarded as the old model.

2. Interaction between an organism's mind, especially with regard to its basic behavioural needs, and the body's health should be an important aspect of modern medicine. 
3. The often subtle interplay between outside (environmental) and inside (genetic) forces should be considered in individualised cases.

4. Smallest parts as such have little meaning, unless they are placed in context.

5. Complexity and self-organized systems do not fit current medical philosophies where clear-cut answers and dramatic, immediate results are expected. However, if one wants to deal with truth and reality in medicine, these concepts should form part of diagnosis and therapy.

6. Medical and mathematical approaches in biology have their limitations. There is no formula for animal welfare, nor will human emotion enhance it. Animal welfare and well-being should be approached according to modern science which is based on the ability to integrate multifactorial knowledge in a perspective which reflects a reality here and now.

Following this approach may also have implications for the way in which veterinary students are taught.

7. Basic veterinary subjects, such as Anatomy (parts), Physiology (function) and Genetics (potential), only make sense when they are understood in the context of the complete, self-organised organism bred for a specific purpose and in relation to a specific environment.

8. Diagnostic subjects, such as Bacteriology, Heiminthology, Mycology, Parasitology, Pathology, Protozoology, Toxicology, Virology and Epidemiology, can only be dealt with as aetiologies when the causes of the causes as variables in the environment and the animal also become part of the diagnosis.

9. Clinical subjects such as Surgery, Medicine and Theriogenology can only be considered as therapy as long as they go beyond short term and immediate care. A perspective on causes of causes should also provide aftercare, which is aimed at longterm strategies, if not permanent solutions. Prevention of the repetition of the same conditions should thus be part of the clinical approach.

10. Veterinary Science needs a subject equivalent to Health Psychology. In such a subject the animal's behaviour and needs should be the premise to health. If Animal Husbandry and Management are approached from an animal welfare point of view, i.e. based on the knowledge of animal needs, it is also based on the study of animal behaviour. Where Psychology is the study of human behaviour and Ethology the term used for the study of animal behaviour, the subject in Veterinary Science should be known as Health Ethology - a subject, which should deal directly with the animal's welfare and well-being.

Health Ethology in Practice

Arguments up till now demonstrated the relationship between animaI welfare and new developments in human medicine, modern epistemologies in natural science and in particular biology, the intriguing interaction between physical environment and genetics, as well as the possible effects of these developments on veterinary training. The question still remains, how would the new approach sediment in practice? If it does not make sense in practice, it does not make sense to veterinarians. To promote animal welfare in practice, Health Ethology can be applied in three phases.

Knowledge

In human societies, people take the responsibility for their own care and welfare. This could include self-care, mutual care or care for others. This obviously happens in an environment in which people usually live. As for other organisms, in the study of Phenomenology it is assumed that humans shape their own world, despite the fact that the world is also shaping them (Kruger 1988). Our actions, plans and decisions determine our future and in that sense the future is coming to us, or in other words we do not move towards 
a totally unknown future. Part of the future is already determined by ourselves and that part is coming to us instead of us moving towards it (Van den Berg 1972).

With regard to animals in our care (domesticated animals), in one sense it is different, but in another it is not. Animals that live in man-made environments and that have been shaped by preplanned selection have very little impact on what their future holds. On the other hand, our ownership to a great extent determines the kind of future, which is approaching the animal.

It is not certain whether animal owners always fully realise their responsibility for determining the quality of an animal's future when they decide to keep animals. If the animal's welfare and well-being were not part and parcel of the decision to keep it, a poor future is on its way for the animal. Such a future will include disease, trauma and behavioural problems.

Animal ownership should thus begin with knowledge to secure the animal's welfare. Every owner cannot be expected to have such knowledge readily available. However, veterinarians can be expected to have the necessary knowledge about their "patients". Furthermore, it is the veterinarian's responsibility to be able to communicate such knowledge to the owner. It may not be by accident that the etymon for communication in Latin is "communi-care". One can say that to communicate properly is to care.

What knowledge should the veterinarian be able to communicate? Well, it is at this point that the veterinarian should have developed the skills to integrate facts to understand complex phenomena and to make this part of everyday practice. Before such application can be done, let one consider what facts should be integrated. First of all, the specific animal's needs and the purpose it is kept for should be known. The interplay between genetics (adaptation for the individual and selection for breeding) and environment should be attended to. Inadaptability and selection side-effects could be detrimental to the animal's health and should therefore be the veterinarian's concern. A thorough knowledge of animal behaviour, physiology and genetics is necessary to find a dynamic equilibrium between the domesticated animal's needs and its man-made environment.

Health ethology

Knowledge per se will not enhance the animal's welfare and well-being. The knowledge needs to be translated into the real-life situation of a specific animal. Animal management is often based on what the owner thinks the best way is to get the most out of the animal for the owner. Mistakes in this regard could either be a mechanistic or an anthropomorphic approach to animal husbandry. The veterinary approach should be that of Health Ethology, which implies that the premise should be knowledge of the animal's needs as described in the previous section. Animal care and keeping should thus be based on this knowledge. Questions veterinarians should ask themselves are how often they get involved in the animal's needs as a whole organism, and how often they get involved in the relationship between the entire animal and the environment provided for it? Are veterinarians not too often only involved in a problem-orientated solution, where the problem is a single clinical cause, treated by a single clinical treatment? Even preventive medicine could in some instances become obsolete by creating environments and circumstances, which promote conditions that do not need preventive medicine. If the presence of animals is planned to be in balance with the animal's environment, some disease conditions will not occur (Fig 1).

Veterinarians' involvement in animal care is no simple task, but it is their primary involvement in animal welfare. To emphasize this important aspect, one can state that clinical veterinary work is an indication of failure in animal welfare.

\section{Products and Uses}

People do not keep animals for no particular reason. There are various motivations for people to keep animals. Reasons for keeping companion animals do not necessarily focus 


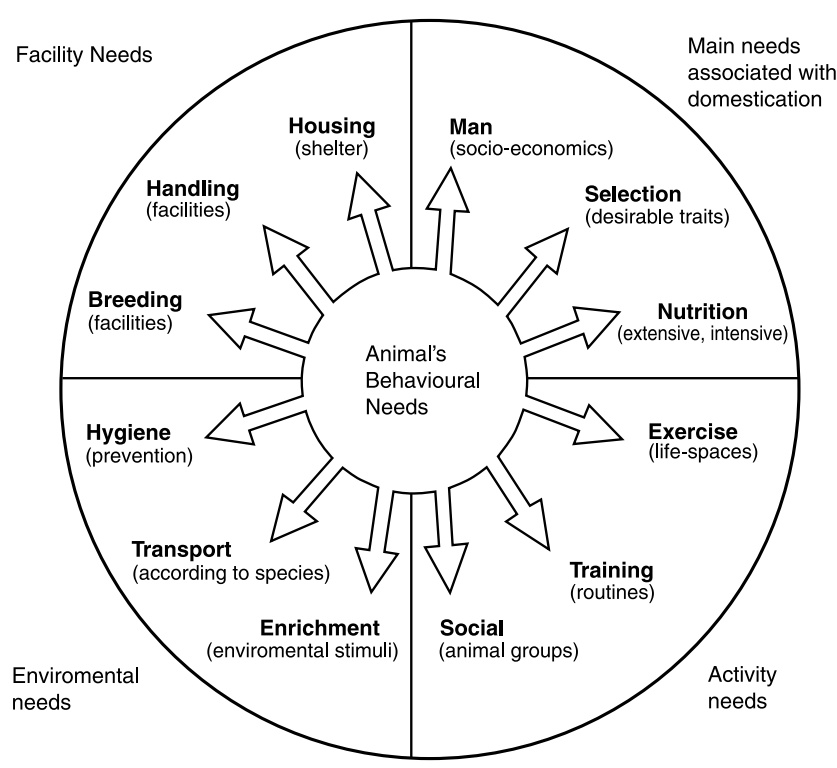

Fig.1. Contextual diagnosis (from Odendaal 1998)

primarily on the animal as such, but could also fulfill human emotional needs (Odendaal and Weyers 1990). Whatever the case may be, animal owners became owners to benefit in some way from ownership, either by using animal products or by using animals for emotional and sentimental reasons.

If the care of animals in the previous section is based on the knowledge of the first section, the products and uses of animals should be based on the care provided to them. In typical human terms one can say that care is input and that products and uses are output. In other words, animal products and uses should be based on Health Ethology. If health becomes a guideline in animal keeping, it is clear that we deal with a fundamental veterinary subject. It also follows that products and uses should not be maximized, but optimized, because maximum output always has health-related side-effects (Fig 2).

\begin{tabular}{|c|c|c|c|}
\hline $\begin{array}{l}\text { KNOWLEDGE } \\
\text { (species' needs) }\end{array}$ & $\rightarrow$ & $\begin{array}{c}\text { INPUT } \\
\text { (care and environment) }\end{array}$ & $\begin{array}{c}\text { OUTPUT } \\
\text { (uses/product) }\end{array}$ \\
\hline
\end{tabular}

Fig. 2. Health Ethology

\section{Summary}

Health Ethology is the study of domesticated animal needs from a veterinary point of view, to enhance animals' health - health as defined in welfare and well-being. It will bring about a fresh orientation and in some cases a complete change of mind among veterinarians with regard to the role they have to fulfill as part of their professional duty. This role will be based on facts used along the most modern views in science and biology. If conventional textbook facts cannot be applied in this contextual way, veterinarians have made no progress since the initial recognition of the profession.

What now about the clinical expertise which made veterinary science what it is? It is not 
a matter of one approach against the other. Clinical work should, however, be made part of the bigger picture, a picture which will go further than immediate results. This picture should truly and honestly have the animal's welfare in mind. If veterinarians stick to their clinical skills only, they really miss the opportunity to be the professional animal welfarists of the world. Remember, animal welfare does not lie so much in relieving, healing or feeling, as in revealing the context. This context has to do with practical reality and it should be the basis of all veterinary science, as it is after all part of modern science. At the same time, the contextual approach places veterinary science in the centre of true animal welfare.

\section{Nemoc jako kompromis pohody zvírat}

Veterináři se obvykle snaží nelézat přímé přičiny nemocí, traumat nebo problémového chování, aby mohli rozhodnout o terapeutickém režimu. Málokdy se ptají po příčině příčiny.

V humánní medicíně se vyvinula nová disciplina - psychologie zdraví, zabývající se vztahem mezi chováním a zdravím. Takový přístup, postihující interakce prostředí a organismu, činí sice diagnózu složitější, ale může lépe odrážet realitu. Ve veterinární terminologii by se tato disciplína mohla nazývat etologií zdraví a zabývat se potřebami zvírat $\mathrm{v}$ particular určitém prostředí. Hodnotíme-li klinické podmínky z tohoto pohledu, kontextuální diagnózu lze připojit k diagnóze klinické. To znamená, že příčiny příčin se stávají součástí pohody, welfare zvířat v praxi.

Welfare zviŕrat v praxi pak nespočívá toliko v tradičním ulevování bolesti a léčení neduhů či zviŕrat či emocionálních problémů člověka, ale v odhalování kontextů. Kontextuální diagnóza pak umistuje veterinární medicínu do centra skutečné péče o zvířata.

\section{References}

BARROW, J. D. 1992: Theories of everything - the quest for ultimate explanation. Cox \& Wyman Ltd, London,: $223 \mathrm{p}$.

BELLOC, N. D. BRESLOW, L. 1972: Relationship of physical health status and family practices. Preventive Medicine (1): 409-421

BRESLOW, L. 1983: The potential of health promotion. In: Handbook of health, health care, and the health profession. Ed Mechanic D Free Press, New York, 201 p.

COHEN, J. STEWART I. 1994: The Collapse of Chaos - discovering simplicity in a complex world. Penguin Books, London, 435 p.

DAVIES, P. J. 1990: Introduction. In: Physics and philosophy, Heisenberg, W, Penguin Books, London, pp. 1-14

DAVIES, P. J. 1995: The cosmic blueprint-order and complexity at the edge of chaos, Penguin Books, London, $223 \mathrm{p}$.

ENGEL, G. L. 1977: The need for a new medical model: A challenge for biomedicine. Science 196: 129-136

KRUGER, D. 1988: An introduction to Phenomenological Psychology. Juda \& Co Ltd, Cape Town, 235 p.

LAU, R. R., HARTMAN, K .A. 1983: Common sense representations of common illnesses. Health Psychology (2): $167-185$

LEWONTIN, R. C. 1993: The doctrine of DNA-biology as ideology. Penguin Books, London: pp 45-46, 109

LINDLEY, D. 1993: The end of Physics - the myth of a unified theory. Basic Books, New York, $275 \mathrm{p}$.

ODENDAAL, J. S. J., WEYERS, A. 1990: Human-Companion-animal relationships in the veterinary consulting room. J. South Afr. Vet. Assoc. 61: 14-23

ODENDAAL, J. S. J. 1998: Animal welfare in practice. Appl. Anim. Behav. Sci. 59: 93-99

PRIGOGINE, I., STENGERS, 1984:Order out of Chaos - rnan's new dialogue with nature. Harper Collins Publishers, London, 349 p.

STERNBERG, R. J. 1995: In search of the human mind. Harcourt Brace \& Co, Orlando, Florida, 741 p.

SCHWARTZ, G. E. 1982: Testing the biopsychosocial model: The ultimate challenge facing behavioural medicine. J. Consulting and Clinical Psychology 50: 1040-1053

VAN DEN BERG, J. H. 1997: A Different Existence. Duquesne University Press, Pittsburg, Pennsylvania, 112 p.

WEINBERG, S. 1993: Dreams of a final theory. Cox \& Wyman, Berkshire, 260 p. 